\title{
Pengujian Kepresisian Modul GNSS Murah Dual Frequency Pada Pengamatan GNSS Dengan Metode RTK-NTRIP
}

\author{
EFRILA AJI RATNAWATI, HENRI KUNCORO
}

\author{
Jurusan Teknik Geodesi \\ FTSP - Institut Teknologi Nasional, Bandung \\ Email: efrilaa@gmail.com
}

\begin{abstract}
ABSTRAK
GNSS berkembang dengan pesat seiring berkembangnya zaman. Dominasi dari receiver GNSS tipe geodetik memiliki kekurangan, yaitu terkait permasalahan biaya (cost issue) yang tinggi. Permasalahan biaya tersebut dapat diatasi dengan pengembangan Original Equipment Manufacturer boards (OEMboards) yang memerlukan biaya murah untuk menjadi modul GNSS yang bisa digunakan untuk pengukuran RTK-NTRIP. Penelitian ini bertujuan menguji tingkat kepresisian dari modul GNSS murah dual frequency untuk pengukuran metode RTK-NTRIP dengan panjang baseline 0,1 km, $2 \mathrm{~km}, 10 \mathrm{~km}$, dan 20 km. Pengukuran dilakukan berdasarkan New International Standard ISO 17123-8:2015 yang terdiri dalam tiga tahap, yaitu pengukuran menggunakan receiver GPS geodetik metode statik, pengukuran menggunakan modul GNSS murah dual frequency, dan pengukuran menggunakan receiver geodetik metode RTK-NTRIP. Kepresisian ditentukan berdasarkan simpangan baku horizontal dan vertikal, diuji menggunakan Simplified Test Procedure. Tingkat kepresisian yang dihasilkan modul GNSS murah tergolong tinggi, untuk komponen horizontal berkisar antara $8 \mathrm{~mm}$ s.d. $3 \mathrm{~cm}$ dan vertikal antara $7 \mathrm{~mm}$ s.d. $3 \mathrm{dm}$. Nilai kepresisian horizontal telah memenuhi standar yang ditetapkan oleh New International Standard ISO 17123-8:2015, sedangkan komponen vertikal tingkat kepresisiannya terbatas pada baseline kurang dari $10 \mathrm{~km}$.
\end{abstract}

Kata kunci: Panjang baseline, modul GNSS murah; tingkat kepresisian

\begin{abstract}
GNSS was a technology that grows rapidly. Unfortunately, most of geodetic GNSS receivers had disadvantages related to the cost issue. Original Equipment Manufacturer boards (OEM-boards) could be developed as low cost GNSS modules which is used for RTK-NTRIP measurements to overcome the cost problem. This research was objected to measure the level of precision from dual-frequency GNSS modules of the RTK-NTRIP method, tested on baselines with $0.1 \mathrm{~km}, 2 \mathrm{~km}, 10 \mathrm{~km}$, and $20 \mathrm{~km}$ length Based on New International Standard ISO 17123-8: 2015 measurements were established with three stages, static measurement with geodetic GPS receiver, measurement with cheap dual-frequency GNSS modules, and RTK-NTRIP measurements with geodetic GPS receiver. Precision was determined based on horizontal and vertical standard deviation and tested using the Simplified Test Procedure. It was founded that low cost GNSS modules could achieved the the high-level precision, $8 \mathrm{~mm}$ to $3 \mathrm{~cm}$ for horizontal component and $7 \mathrm{~mm}$ to $3 \mathrm{dm}$ for the vertical. Horizontal precision had reached the New International Standard ISO 17123-8: 2015, while the vertical precision still could be reached the standard with limitation, i.e. for baselines with less 10 kilometers length.
\end{abstract}

Keywords: baseline length, low cost GNSS modules, level of precision 


\section{PENDAHULUAN}

Peningkatan jumlah perangkat pengguna GNSS untuk keperluan pemetaan tentunya harus diimbangi dengan kemampuan perangkat untuk menghasilkan tingkat kepresisian posisi yang baik, salah satunya adalah dipengaruhi oleh tipe receiver. Tipe receiver GNSS untuk keperluan pemetaan didominasi oleh tipe geodetik baik single ataupun dual frequency (GSA, 2018). Namun, dominasi dari receiver GNSS tipe geodetik tersebut memiliki kekurangan, yaitu terkait permasalahan biaya yang tinggi (Schwieger dan Gläser, 2005). Permasalahan biaya tersebut dapat diatasi dengan pengembangan Original Equipment Manufacturer boards (OEM-boards) yang hanya memerlukan biaya $€ 200-300$ menjadi modul GNSS murah (Dabove dan Manzino, 2014).

Modul GNSS murah memungkinkan untuk dilakukan pengukuran penentuan posisi dengan banyak metode karena sudah memiliki spesifikasi dan fitur yang sudah memadahi. Salah satu motode penentuan posisi yang sering diaplikasikan dari modul GNSS murah adalah RTKNTRIP. Saat ini keperluan penentuan posisi yang real-time menggunakan metode RTK dapat diakses secara terbuka dan dimanfaatkan secara luas untuk keperluan pemetaan, yaitu dengan adanya layanan dari Jaringan Indonesian Continuously Operating Reference Station (InaCORS) milik Badan Informasi Geospasial (BIG, 2018) atau Jaringan Referensi Satelit Pertanahan (JRSP) milik Badan Pertanahan Nasional (BPN).

Pemanfaatan InaCORS milik Badan Informasi Geopasial dalam keperluan penentuan posisi real time menggunakan metode RTK-NTRIP GNSS yang dapat diakses secara terbuka memungkinkan penentuan posisi dengan tingkat presisi yang tinggi tidak lagi sulit dicapai. Tetapi, melihat penggunaan dalam pekerjaan atau penelitian terkait modul GNSS murah untuk penentuan posisi secara RTK masih banyak digunakan modul GNSS murah single frequency dan sekedar langsung digunakan tanpa mengetahui secara riil kepresisian yang dihasilkan apabila dilakukan pada variasi beberapa jarak pengukuran dari base station RTK. Meskipun dari pabrikan modul GNSS murah mencantumkan tingkat kepresisian posisi (horizontal dan vertikal) berdasarkan jarak dengan base station RTK, tetapi melakukan pengujian secara langsung dan mengikuti standar pengujian yang telah ditetapkan merupakan langkah terbaik untuk melihat realitas kemampuan modul GNSS murah untuk penentuan posisi secara RTK.

Penelitian ini bertujuan untuk menguji tingkat kepresisian dari modul GNSS murah dual frequency untuk pengukuran metode RTK-NTRIP dengan panjang baseline 0,1 km, $2 \mathrm{~km}, 10$ $\mathrm{km}$, dan $20 \mathrm{~km}$. Dengan mengetahui tingkat kepresisian modul GNSS murah maka dapat dimanfaatkan untuk keperluan geodesi atau pemetaan yang menuntut kepresisian tinggi seperti survei GNSS, navigasi presisi, pertanian presisi, ataupun pengukuran Ground Control Point (GCP) dalam pemotretan udara dengan UAV. Batasan-batasan yang diterapkan dalam penelitian ini di antaranya adalah: jenis pengukuran RTK-NTRIP memanfaatkan single-base correction dari layanan InaCORS, provider sinyal internet yang digunakan adalah Telkomsel, penentuan panjang maksimum baseline mengacu ke penelitian Tominaga, dkk. (2004), prosedur pengukuran RTK GNSS mengacu ke New International Standard ISO 17123-8:2015 (Heister, 2008; Zrinjski dkk., 2016), dan satelit GNSS yang akan digunakan dalam penelitian ini adalah GPS, GLONASS, dan BeiDu.

\section{METODOLOGI}

Metodologi yang akan digunakan pada penelitian mengenai pengujian kepresisian modul GNSS murah dual frequency pada pengamatan GNSS dengan metode RTK-NTRIP dapat dilihat pada Gambar 1. 


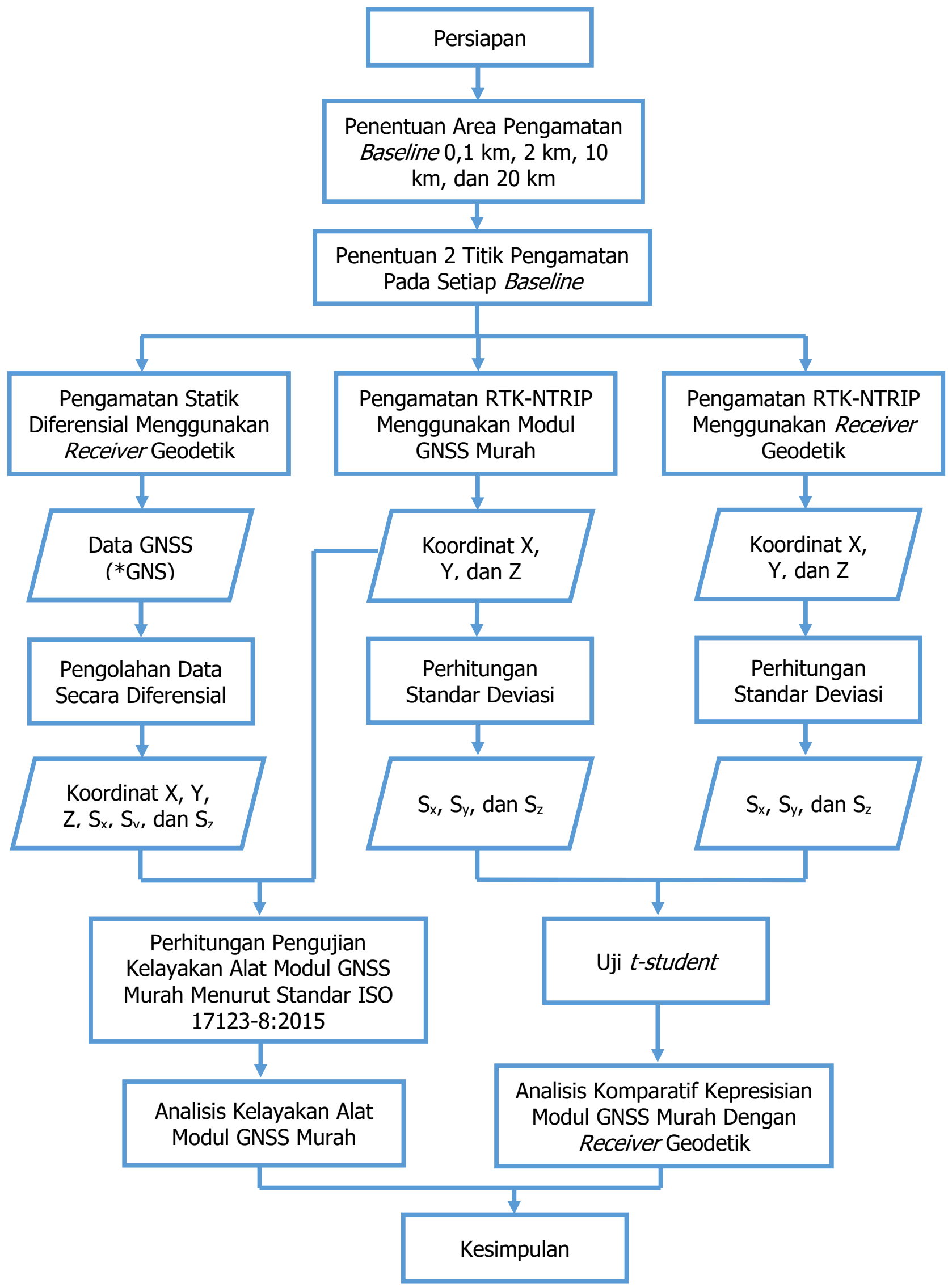

Gambar 1. Metodologi Penelitian

Reka Geomatika - 12 
Data yang digunakan dalam penelitian ini adalah data hasil dari pengukuran yang dilakukan dengan pengamatan GNSS secara statik diferensial selama satu jam dan secara RTK-NTRIP. Data yang diperoleh dari pengukuran tersebut merupakan raw data pengamatan GNSS geodetik dengan format .GNS yang kemudian dikonversi ke format .RINEX sehingga dapat dilakukan post processing dan koordinat hasil pengukuran secara RTK-NTRIP menggunakan GNSS geodetik dan Modul GNSS murah dual frequency di titik yang akan diukur koordinatnya. Sampel data .RINEX dapat dilihat pada Gambar 2 dan data koordinat hasil pengukuran RTKNTRIP dapat dilihat pada Tabel 1.

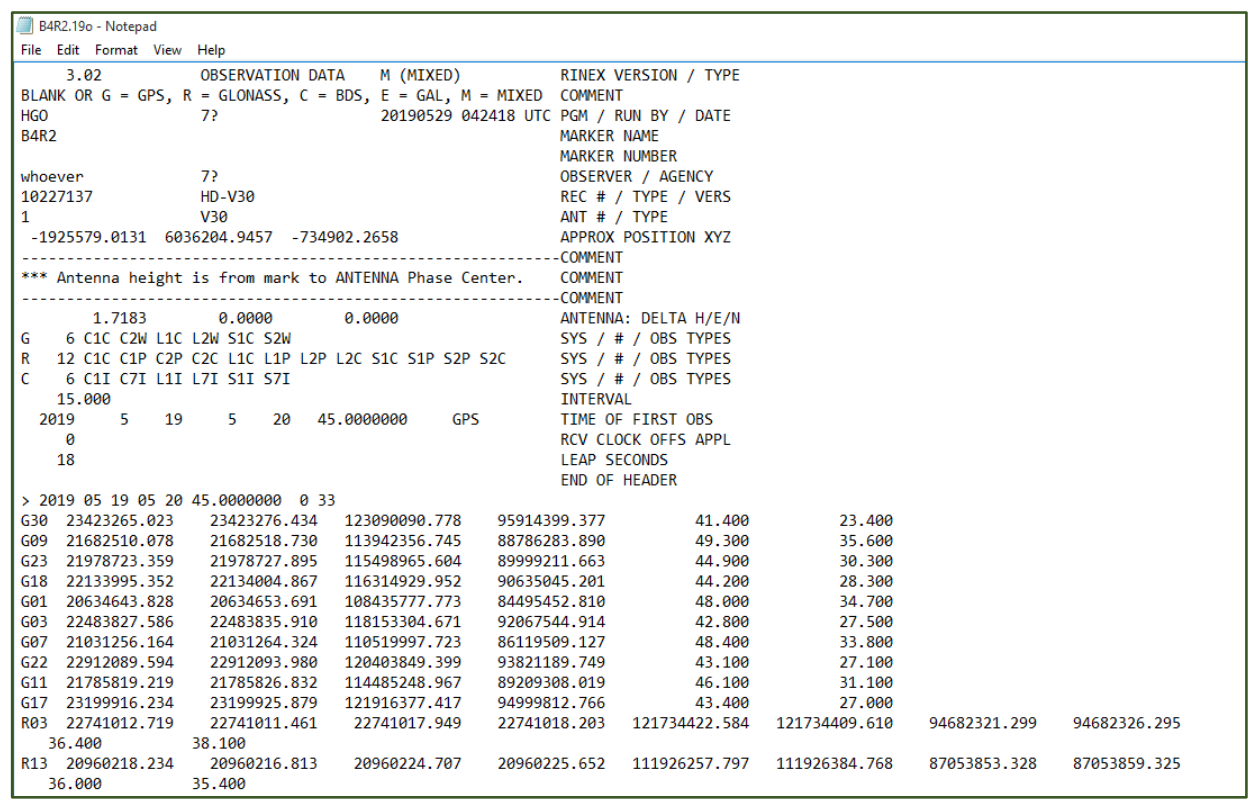

Gambar 2. Sampel data dalam format .RINEX

Tabel 1. Sampel data koordinat hasil pengukuran RTK-NTRIP

\begin{tabular}{cccc}
\hline No. & $\mathbf{X}(\mathbf{m})$ & $\mathbf{Y}(\mathbf{m})$ & $\mathbf{Z}(\mathbf{m})$ \\
\hline 1 & $789.259,9068$ & $9.244 .842,1544$ & $1.319,2180$ \\
2 & $789.259,9026$ & $9.244 .842,1653$ & $1.319,2230$ \\
3 & $789.259,8909$ & $9.244 .842,1710$ & $1.319,2120$ \\
4 & $789.259,9004$ & $9.244 .842,1616$ & $1.319,1950$ \\
5 & $789.259,8977$ & $9.244 .842,1570$ & $1.319,2150$ \\
\hline
\end{tabular}

3. HASIL DAN PEMBAHASAN

\subsection{Analisis Koordinat Statik Diferensial}

Koordinat referensi digunakan sebagai acuan pengecekan kepresisian sistem pengukuran lapangan GNSS dalam metode penentuan posisi secara RTK. Menurut Zrinjski dkk., (2016) dengan metode geodetik yang kepresisiannya lebih tinggi dari metode GNSS RTK dapat digunakan sebagai acuan untuk penentuan suatu posisi dan nilai tertentu dari kuantitas tersebut yang dinyatakan sebagai nilai acuan/referensi. Hasil koordinat referensi ini menggunakan sistem koordinat SRGI 2013 dengan sistem proyeksi UTM. Hal tersebut dikarenakan sistem koordinat referensi yang digunakan harus sama dengan sistem referensi koordinat RTK (Quraisy, 2014). Hasil koordinat referensi dapat dilihat pada Tabel 2 dengan standar deviasi masing-masing komponen koordinat pada Tabel 3. 
Tabel 2. Koordinat Referensi

\begin{tabular}{cccccccc}
\hline $\begin{array}{c}\text { Nama } \\
\text { Titik }\end{array}$ & $\begin{array}{c}\text { Panjang } \\
\text { Baseline } \\
(\mathbf{m})\end{array}$ & $\mathbf{E}(\mathbf{m})$ & $\mathbf{N}(\mathbf{m})$ & $\mathbf{h}(\mathbf{m})$ & $\begin{array}{c}\boldsymbol{\sigma}_{\Delta E} \\
(\mathbf{m})\end{array}$ & $\begin{array}{c}\boldsymbol{\sigma}_{\Delta \mathbf{N}} \\
(\mathbf{m})\end{array}$ & $\begin{array}{c}\boldsymbol{\sigma}_{\Delta \mathbf{h}} \\
(\mathbf{m})\end{array}$ \\
\hline B1R1 & 162,768 & $789.259,866$ & $9.244 .842,158$ & $1.319,226$ & 0,0002 & 0,0004 & 0,0002 \\
B1R2 & 159,433 & $789.251,585$ & $9.244 .824,160$ & $1.318,508$ & 0,0004 & 0,0007 & 0,0003 \\
B2R1 & $2.024,012$ & $791.084,739$ & $9.245 .266,749$ & $1.233,673$ & 0,0004 & 0,0007 & 0,0002 \\
B2R2 & $2.037,434$ & $791.100,701$ & $9.245 .254,965$ & $1.233,274$ & 0,0003 & 0,0006 & 0,0002 \\
B3R1 & $10.216,554$ & $795.823,452$ & $9.237 .193,765$ & 787,906 & 0,0039 & 0,0079 & 0,0027 \\
B3R2 & $10.228,593$ & $795.819,471$ & $9.237 .174,280$ & 787,736 & 0,0042 & 0,0110 & 0,0043 \\
B4R1 & $20.078,930$ & $797.772,758$ & $9.262 .977,302$ & 520,494 & 0,0028 & 0,0046 & 0,0018 \\
B4R2 & $20.078,291$ & $797.754,367$ & $9.262 .985,410$ & 520,979 & 0,0037 & 0,0028 & 0,0015 \\
\hline
\end{tabular}

Standar deviasi koordinat yang didapatkan bertujuan untuk mengetahui seberapa besar kepresisian koordinat statik diferensial yang dihasilkan sehingga dapat ditentukan layak atau tidaknya untuk menjadi koordinat referensi. Pada Tabel 2 ditunjukkan bahwa dari seluruh komponen koordinat E memiliki nilai standar deviasi yang terkecil sebesar 0,0002 meter atau 0,2 milimeter pada titik B1R1, sedangkan nilai standar deviasi yang terbesar adalah 0,0042 meter atau 4,2 milimeter pada titik B3R2. Untuk seluruh komponen koordinat $\mathrm{N}$ nilai standar deviasi yang terkecil sebesar 0,0004 meter atau 0,4 milimeter pada titik B1R1, sedangkan nilai standar deviasi yang terbesar adalah 0,0110 meter atau 10,2 milimeter pada titik B3R2, dan untuk seluruh komponen koordinat $h$ nilai standar deviasi yang terkecil sebesar 0,0002 meter atau 0,2 milimeter pada titik B1R1, B2R1 dan B2R2, sedangkan nilai standar deviasi yang terbesar adalah 0,0043 meter atau 4,3 milimeter pada titik B3R2. Hal tersebut dapat dikatakan bahwa pada titik B3R2 memiliki tingkat kepresisian yang paling rendah dari pada titik yang lain, tetapi jika digunakan sebagai referensi dari pengukuran RTK masih layak karena nilai tersebut masih di atas standar dari standar deviasi horizontal dan vertikal untuk pengukuran RTK. Menurut Sioulis dkk. (2015) untuk pengukuran real time kinematic(RTK) dengan standar deviasi horizontal $\leq 0,027 \mathrm{~m}$ dan vertikal $\leq 0,046 \mathrm{~m}$ mampu memenuhi standar ketelitian ISO kelas RT2.

\subsection{Analisis Kepresisian Modul GNSS Murah Dual Frequency}

Simpangan baku hasil pengukuran modul GNSS murah pada setiap baseline dapat dilihat pada Tabel 3.

Tabel 3. Nilai Simpangan Baku Hasil Pengukuran Modul GNSS Murah pada Setiap Baseline

\begin{tabular}{|c|c|c|c|c|c|c|c|c|}
\hline \multirow{3}{*}{$\begin{array}{c}\text { Panjang } \\
\text { Baseline } \\
(\mathrm{km})\end{array}$} & \multicolumn{4}{|c|}{$S_{x y}(m)$} & \multicolumn{4}{|c|}{$S_{h}(m)$} \\
\hline & \multicolumn{2}{|c|}{ R1 } & \multicolumn{2}{|c|}{ R2 } & \multicolumn{2}{|c|}{ R1 } & \multicolumn{2}{|c|}{ R2 } \\
\hline & GD & LC & GD & LC & GD & LC & GD & LC \\
\hline 0,1 & 0,008881 & 0,014953 & 0,006963 & 0,011225 & 0,010644 & 0,011402 & 0,014007 & 0,013038 \\
\hline 2 & 0,025112 & 0,012965 & 0,021324 & 0,008155 & 0,012845 & 0,007071 & 0,014926 & 0,008944 \\
\hline 10 & 0,024979 & 0,022808 & 0,032540 & 0,021831 & 0,054125 & 0,301198 & 0,034967 & 0,305320 \\
\hline 20 & 0,038561 & 0,024928 & 0,032725 & 0,028455 & 0,054614 & 0,378048 & 0,037632 & 0,377849 \\
\hline
\end{tabular}


Pada Tabel 3 ditunjukkan bahwa nilai kepresisian dari modul GNSS murah dapat mencapai hingga 0,0081 meter atau 8 milimeter pada baseline 2 kilometer Rover 2 dan untuk kepresisian horizontal, sedangkan untuk kepresisian vertikal nilai yang dicapai adalah 0,0070 meter atau 7 milimeter untuk baseline 2 kilometer Rover 1 . Tingkat kepresisian yang dihasilkan oleh modul GNSS murah ini bergantung pada pemilihan tempat yang ditentukan untuk melakukan pengukuran. Hal tersebut dibuktikan dari hasil pengukuran bahwa pada baseline $2 \mathrm{~km}$ memiliki nilai kepresisian yang lebih kecil daripada nilai kepresisian pada baseline 0,1 km yang memiliki nilai kepresisian horizontal sebesar $1,49 \mathrm{~cm}$ untuk Rover 1, 1,12 cm untuk Rover 2 dan kepresisian vertikal 1,14 cm untuk Rover 1, 1,3 cm untuk Rover 2. Hal tersebut dikarenakan pengukuran pada baseline $2 \mathrm{~km}$ terletak pada kebun terbuka, tidak terdapat banyak rumput dan tidak terdapat banyak bangunan, sedangkan pada baseline 0,1 km terletak pada tempat terbuka, tetapi terdapat beberapa bangunan dan pepohonan.

Pada Gambar 3 dan 4 dapat dilihat trend simpangan baku horizontal hasil dari Rover 1 dan Rover 2 untuk semua baseline menggunakan modul GNSS murah dengan receiver geodetik. $\mathrm{S}_{\mathrm{xy}}$ merupakan simpangan baku horizontal dalam satuan meter, LC merupakan plotting hasil simpangan baku dari modul GNSS murah dan GD merupakan plotting hasil simpangan baku dari receiver geodetik. Pada kedua trend ini dapat dilihat bahwa semakin panjang baseline maka semakin tinggi pula simpangan baku yang dihasilkan atau dengan kata lain berarti semakin panjang baseline maka semakin rendah tingkat kepresisiannya, hal ini berlaku untuk modul GNSS murah maupun receiver geodetik. Untuk komponen horizontal perbandingan kepresisian modul GNSS murah dengan receiver geodetik tidak terlalu signifikan setiap antar baseline atau masih dapat dikatakan mempunyai perbedaan kurang lebih 1 sampai dengan 2 $\mathrm{cm}$. Bahkan pada grafik tersebut ditunjukkan pada baseline $10 \mathrm{~km}$ dan $20 \mathrm{~km}$ untuk Rover 1 maupun Rover 2 bahwa kepresisian horizontal modul GNSS murah lebih baik daripada kepresisian receivergeodetik untuk pengukuran RTK-NTRIP. Hal ini berarti modul GNSS murah memiliki tingkat kepresisian yang bagus untuk komponen horizontal dalam pengukuran RTKNTRIP.

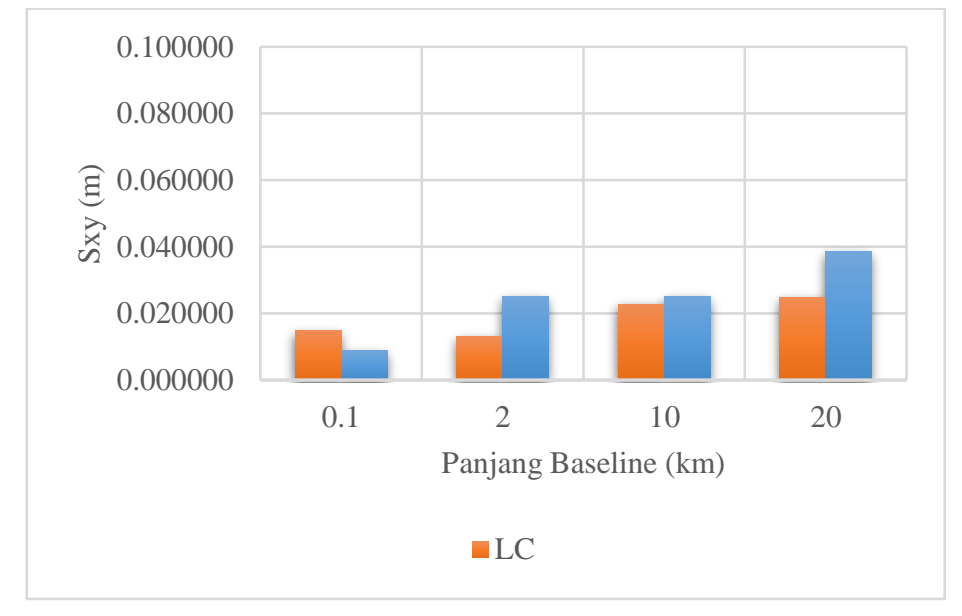

Gambar 3. Simpangan Baku Horizontal pada Rover 1

Pada Gambar 5 dan 6 dapat dilihat trend simpangan baku vertikal hasil pengukuran menggunakan modul GNSS murah dan receiver geodetik. Pada trend ini terlihat simpangan baku vertikal pada baseliene 0,1 km dan 0,2 km memiliki nilai yang kecil atau dapat dikatakan bahwa tingkat kepresisiannya tinggi, tetapi terlihat juga sangat jelas perbedaan pada baseline 10 sampai $20 \mathrm{~km}$ antara modul GNSS murah dengan receiver geodetik pada Rover 1 maupun Rover 2, nilai kepresisian yang dihasilkan modul GNSS murah mencapai lebih dari $30 \mathrm{~cm}$ atau $3 \mathrm{dm}$, sedangkan nilai kepresisian yang dihasilkan oleh receiver geodetik masih dalam batas 
sentimeter. Berdasarkan hal tersebut maka dapat dikatakan bahwa modul GNSS murah memiliki tingkat kepresisian pengukuran RTK-NTRIP yang kurang baik untuk komponen vertikal dengan jarak baseline yang cukup jauh dari stasiun base, sedangkan untuk receiver geodetik memiliki tingkat kepresisian vertikalnya masih dalam batas sentimeter dan masih stabil untuk setiap panjang baseline yang ditentukan.

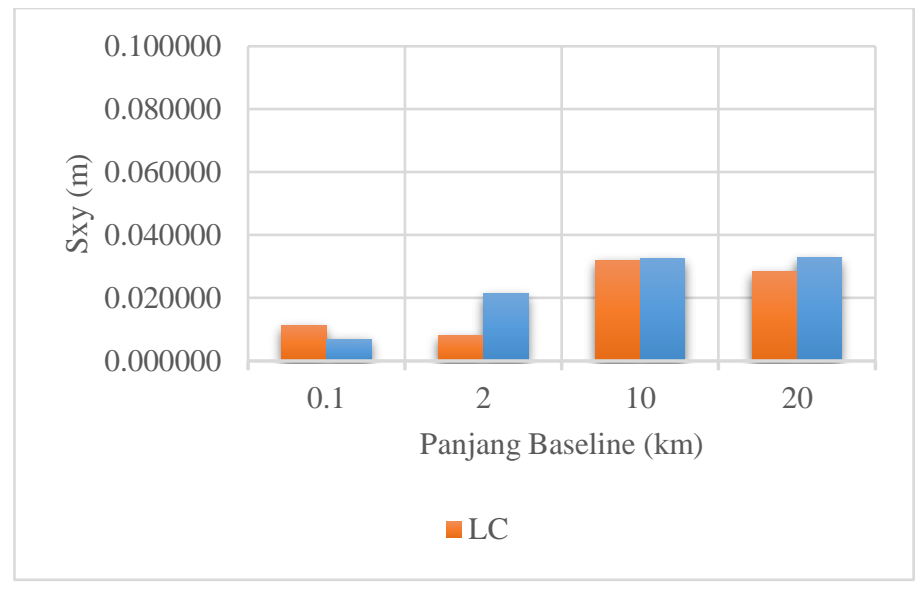

Gambar 4. Grafik Simpangan Baku Vertikal pada Rover 1

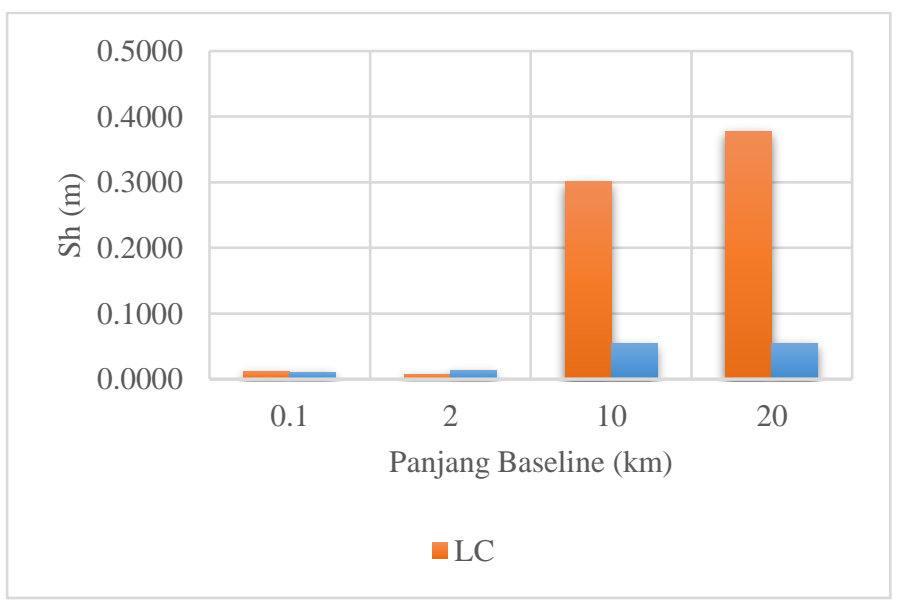

Gambar 5. Trend Simpangan Baku Horizontal pada Rover 2

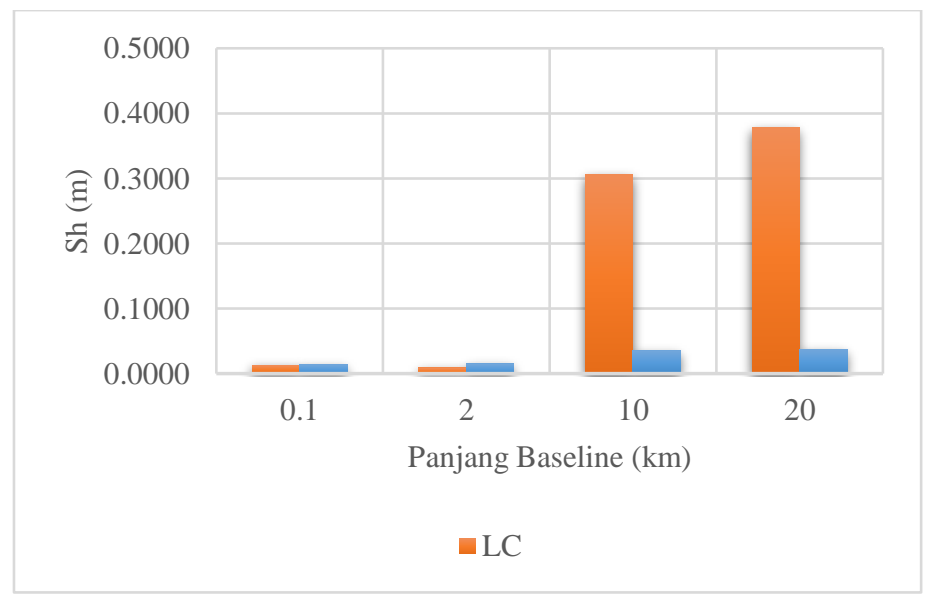

Gambar 6. Trend Simpangan Baku Vertikal pada Rover 2 


\subsection{Hasil Uji-t}

Uji t dikenal dengan uji parsial, yaitu untuk menguji bagaimana pengaruh masing-masing variabel bebasnya secara sendiri-sendiri terhadap variabel terikatnya. Uji ini dapat dilakukan dengan mambandingkan $t_{\text {hitung }}$ dengan $\underline{t}_{\text {tabel }}$ atau dengan melihat kolom signifikansi pada masing-masing thitung (Hidayat, 2013). Dengan kata lain t-uji ini digunakan untuk membandingkan seberapa signifikan perbedaan antar data dengan variabel yang berbeda. Pada penelitian ini digunakan taraf signifikansi 0,5, uji dua arah, dan derajat kebebasan 8 yang mempunyai nilai $\mathrm{t}_{\text {tabel }}$ sebesar 2,306, dengan hipotesis terima $\mathrm{H}_{0}$ dan tolak $\mathrm{H}_{\mathrm{a}}$ jika, $\mathrm{t}_{\text {hitung }}<\mathrm{t}_{\text {tabel }}$ atau tolak $\mathrm{H}_{0}$ dan terima $\mathrm{H}_{a}$ jika thitung $>\mathrm{t}_{\text {tabel. }}$. Hal tersebut berarti bahwa jika $\mathrm{H}_{0}$ diterima dan $\mathrm{H}_{\mathrm{a}}$ ditolak maka hasil pengukuran antara receiver geodetik dan modul GNSS murah memiliki hasil pengukuran yang setara, tetapi jika $\mathrm{H}_{0}$ ditolak dan $\mathrm{H}_{a}$ diterima maka hasil pengukuran antara receiver geodetik dan modul GNSS murah memiliki perbedaan hasil pengukuran yang signifikan.

Tabel 4. Hasil Uji-t

\begin{tabular}{crr}
\hline \multirow{2}{*}{ Baseline } & \multicolumn{2}{c}{ Komponen } \\
\cline { 2 - 3 } & Horizontal & \multicolumn{1}{l}{ Vertikal } \\
\hline 0,1 & 1,55351 & $-1,63425$ \\
2 & 0,78882 & 0,30499 \\
10 & 1,99893 & 4,47912 \\
20 & 2,12228 & $-4,69609$ \\
\hline
\end{tabular}

Pada Tabel 4 ditunjukkan adanya penolakan $\mathrm{H}_{0}$ dan diterimanya $\mathrm{H}_{a}$ dari pengujian hasil pengukuran antara modul GNSS murah dengan receiver geodetik pada baseline 10 dan $20 \mathrm{~km}$ untuk komponen vertikal dengan bukti thitung $>t_{\text {tabel }}$ yang memiliki nilai 4,47912>2,306 (baseline $10 \mathrm{~km}$ ) dan -4,69609 > -2,306 (baseline $20 \mathrm{~km}$ ), yang berarti bahwa hasil pengukuran dari kedua alat pada baseline 10 dan $20 \mathrm{~km}$ memiliki perbedaan yang signifikan untuk komponen vertikal. Hal tersebut berarti bahwa hasil pengukuran komponen vertikal pada baseline 10 dan $20 \mathrm{~km}$ lebih baik menggunakan receiver geodetik. Tingkat kepresisian yang dihasilkan oleh modul GNSS murah pada panjang baseline tersebut sudah mencapai kurang lebih 30 sentimeter, sedangkan tingkat kepresisian yang dihasilkan oleh receiver geodetik masih dalam tingkat kurang lebih 2-3 sentimeter.

Uji-t untuk komponen horizontal pada semua baseline menghasilkan hipotesis penerimaan $\mathrm{H}_{0}$ dan penolakan $\mathrm{H}_{\mathrm{a}}$ dengan nilai $\mathrm{t}_{\text {hitung }}<\mathrm{t}_{\text {tabel }} 1,55351<2,306$ untuk baseline 0,1 km, 0,78882 $<2,306$ untuk baseline $2 \mathrm{~km}, 1,99893<2,306$ untuk baseline $10 \mathrm{~km}$, dan 2,12228<2,306 untuk baseline $20 \mathrm{~km}$. Hal tersebut berarti bahwa hasil pengukuran komponen horizontal dari modul GNSS murah dengan receiver geodetik tidak memiliki perbedaan yang signifikan atau dengan kata lain hasil pengukuran komponen horizontal dari kedua alat tersebut memiliki tingkat yang sama.

\subsection{Pengujian Modul GNSS Murah Dual Frequency Menurut Standar ISO 17123- 8:2015}

ISO 17123-8:2015 merupakan rincian prosedur lapangan untuk dilakukan saat menentukan dan mengevaluasi kepresisian sistem pengukuran lapangan GNSS dalam mode real-time kinematik (GNSS RTK) dan peralatan pendukungnya saat digunakan pada pengukuran bangunan, survei, dan industri. Pengujian ini dilakukan sebagai verifikasi lapangan dari kesesuaian instrumen tertentu untuk aplikasi yang dibutuhkan dan untuk memenuhi persyaratan standar lainnya (ISO, 2015). Pengujian ini dibuat untuk antena GNSS dan receiver seperti pada manual pabrik alat tersebut. Apakah alat yang digunakan sudah sesuai dengan 
ketetapan nilai yang diberikan untuk kepresisiannya. Pada pengujian ini kepresisian suatu receiver GNSS dalam mode real-time kinematik (GNSS RTK) akan memenuhi kondisinya atau layak apabila deviasi penyimpangan jarak horizontal $\left(\left|\varepsilon_{D i, j}\right|\right)$ dan $\left(\left|\varepsilon_{h i, j}\right|\right)$ beda vertikal lebih kecil atau sama dengan nilainya dari $\left(2,5 \cdot \sqrt{2} . S_{x y}\right)$ dan $\left(2,5 \cdot \sqrt{2} \cdot S_{h}\right)$ atau nilai yang asli.

Hasil pengujian modul GNSS murah ditampilkan pada Tabel 5 s.d.8. U ntuk pengukuran pada baseline 0,1 km, $2 \mathrm{~km}$, dan $10 \mathrm{~km}$ komponen horizontal dan vertikal telah terpenuhi semua kondisi kepresisiannya. Untuk baseline $20 \mathrm{~km}$ komponen horizontal telah memenuhi standar yang ditetapkan oleh pabrik pembuatnya, tetapi untuk komponen horizontal tidak terpenuhi. Kondisi ini diperkuat berdasarkan pembahasan mengenai simpangan baku secara manual, kepresisian yang dihasilkan modul GNSS murah menggunakan metode RTK-NTRIP pada baseline $20 \mathrm{~km}$ untuk komponen vertikal memang belum baik atau masih mencapai tingkat dm sehingga disarankan pengukuran menggunakan modul GNSS murah metode RTK-NTRIP untuk digunakan pada baseline kurang dari $20 \mathrm{~km}$ supaya masih memiliki kepresisian komponen vertikal sesuai standar.

Tabel 5. Hasil Pengujian Modul GNSS Murah Berdasarkan Simplified Test Standard ISO 17123-8:2015 pada Baseline 0,1 km

\begin{tabular}{llll}
\hline$\left|\boldsymbol{\varepsilon}_{\boldsymbol{D i}, \boldsymbol{j}}\right| \leq \mathbf{2 , 5} \cdot \sqrt{\mathbf{2}} \cdot \boldsymbol{S}_{\boldsymbol{x y}}$ & Kondisi & $\left|\boldsymbol{\varepsilon}_{\boldsymbol{h i}, \boldsymbol{j}}\right| \leq \mathbf{2 , 5} \cdot \sqrt{\mathbf{2}} \cdot \boldsymbol{S}_{\boldsymbol{h}}$ & Kondisi \\
\hline $0,0032 \leq 0,0357$ & Memenuhi & $0,0076 \leq 0,0534$ & Memenuhi \\
$0,0064 \leq 0,0357$ & Memenuhi & $0,0176 \leq 0,0534$ & Memenuhi \\
$0,0176 \leq 0,0357$ & Memenuhi & $0,0176 \leq 0,0534$ & Memenuhi \\
$0,0073 \leq 0,0357$ & Memenuhi & $0,0076 \leq 0,0534$ & Memenuhi \\
$0,0078 \leq 0,0357$ & Memenuhi & $0,0076 \leq 0,0534$ & Memenuhi \\
\hline
\end{tabular}

Tabel 6. Hasil Pengujian Modul GNSS Murah Berdasarkan Simplified Test Standard ISO 17123-8:2015 pada Baseline 2 km

\begin{tabular}{llll}
\hline$\left|\boldsymbol{\varepsilon}_{\boldsymbol{D i}, \boldsymbol{j}}\right| \leq \mathbf{2 , 5} \cdot \sqrt{\mathbf{2}} \cdot \boldsymbol{S}_{\boldsymbol{x y}}$ & Kondisi & $\left|\boldsymbol{\varepsilon}_{\boldsymbol{h i} \mathbf{j}}\right| \leq \mathbf{2 , 5} \cdot \sqrt{\mathbf{2}} \cdot \boldsymbol{S}_{\boldsymbol{h}}$ & Kondisi \\
\hline $0,0098 \leq 0,0424$ & Memenuhi & $0,0012 \leq 0,0601$ & Memenuhi \\
$0,0059 \leq 0,0424$ & Memenuhi & $0,0012 \leq 0,0601$ & Memenuhi \\
$0,0033 \leq 0,0424$ & Memenuhi & $0,0012 \leq 0,0601$ & Memenuhi \\
$0,0080 \leq 0,0424$ & Memenuhi & $0,0088 \leq 0,0601$ & Memenuhi \\
$0,0063 \leq 0,0424$ & Memenuhi & $0,0188 \leq 0,0601$ & Memenuhi \\
\hline
\end{tabular}

Tabel 7 Hasil Pengujian Modul GNSS Murah Berdasarkan Simplified Test Standard ISO 17123-8:2015 pada Baseline $10 \mathrm{~km}$

\begin{tabular}{llll}
\hline$\left|\boldsymbol{\varepsilon}_{\boldsymbol{D} \boldsymbol{i}, \boldsymbol{j}}\right| \leq \mathbf{2 , 5} \cdot \sqrt{\mathbf{2}} \cdot \boldsymbol{S}_{\boldsymbol{x y}}$ & Kondisi & $\left|\boldsymbol{\varepsilon}_{\boldsymbol{h i}, \boldsymbol{j}}\right| \leq \mathbf{2 , 5} \cdot \sqrt{\mathbf{2}} \cdot \boldsymbol{S}_{\boldsymbol{h}}$ & Kondisi \\
\hline $0,0053 \leq 0,0707$ & Memenuhi & $0,0404 \leq 0,0884$ & Memenuhi \\
$0,0223 \leq 0,0707$ & Memenuhi & $0,0104 \leq 0,0884$ & Memenuhi \\
$0,0228 \leq 0,0707$ & Memenuhi & $0,0096 \leq 0,0884$ & Memenuhi \\
$0,0044 \leq 0,0707$ & Memenuhi & $0,0296 \leq 0,0884$ & Memenuhi \\
$0,0065 \leq 0,0707$ & Memenuhi & $0,0404 \leq 0,0884$ & Memenuhi \\
\hline
\end{tabular}


Tabel 8 Hasil Pengujian Modul GNSS Murah Berdasarkan Simplified Test Standard ISO 17123-8:2015 pada Baseline 20 km

\begin{tabular}{llll}
\hline$\left|\boldsymbol{\varepsilon}_{\boldsymbol{D i} \mathbf{j}}\right| \leq \mathbf{2 , 5} \cdot \sqrt{\mathbf{2}} \cdot \boldsymbol{S}_{\boldsymbol{x y}}$ & Kondisi & $\left|\boldsymbol{\varepsilon}_{\boldsymbol{h i}, \mathbf{j}}\right| \leq \mathbf{2 , 5} \cdot \sqrt{\mathbf{2}} \cdot \boldsymbol{S}_{\boldsymbol{h}}$ & Kondisi \\
\hline $0,0988 \leq 0,1061$ & Memenuhi & $0,2446 \leq 0,1237$ & Tidak \\
$0,0688 \leq 0,1061$ & Memenuhi & $0,0646 \leq 0,1237$ & Memenuhi \\
$0,0743 \leq 0,1061$ & Memenuhi & $0,1446 \leq 0,1237$ & Tidak \\
$0,0822 \leq 0,1061$ & Memenuhi & $0,1846 \leq 0,1237$ & Memenuhi \\
& & Tidak \\
$0,0816 \leq 0,1061$ & Memenuhi & $0,2346 \leq 0,1237$ & Memenuhi \\
\hline
\end{tabular}

\section{KESIMPULAN}

Kesimpulan yang dapat diambil dari penelitian yang sudah dilakukan ini, yaitu: (1) tingkat kepresisian koordinat modul GNSS murah yang dihasilkan berdasarkan standar deviasi horizontal yang didapat menghasilkan nilai terkecil $0,81 \mathrm{~cm}$ pada baseline $2 \mathrm{~km}$ dan nilai tertinggi $2,84 \mathrm{~cm}$ pada baseline $20 \mathrm{~km}$. Standar deviasi vertikal yang didapat menghasilkan nilai terkecil $0,7 \mathrm{~cm}$ pada baseline $2 \mathrm{~km}$ dan nilai tertinggi $37,78 \mathrm{~cm}$ pada baseline $20 \mathrm{~km}$; (2) pada pengujian kepresisian alat berdasarkan standar ISO 17123-8:2015 semua komponen horizontal pada semua baseline modul GNSS murah sudah terpenuhi kelayakannya untuk pengukuran secara RTK; (3) pada pengujian kepresisian alat berdasarkan standar ISO 17123-8:2015 komponen vertikal pada baseline $20 \mathrm{~km}$ modul GNSS murah tidak terpenuhi standar kelayakannya untuk pengukuran secara RTK; (4) berdasarkan hasil uji-t yang dilakukan dengan selang kepercayaan 95\% untuk komponen horizontal pada semua baseline tidak memiliki perbedaan yang signifikan antara modul GNSS murah dengan receiver geodetik atau dapat dikatakan hasil pengukuran kedua alat tersebut sama; (5) berdasarkan hasil uji-t yang dilakukan dengan selang kepercayaan 95\% untuk komponen vertikal pada baseline 10 dan $20 \mathrm{~km}$ memiliki perbedaan yang signifikan antara modul GNSS murah dengan receiver geodetik atau dapat dikatakan lebih baik menggunakan receiver geodetik.

\section{DAFTAR PUSTAKA}

BIG. (2018). Mengenal Sistem InaCORS. In B. G.-P. Geodinamika, InaCORS BIG Satu Referensi Pemetaan Indonesia (p. 35). Cibinong: Badan Informasi Geospasial.

Dabove, P., dan Manzino, A. M. (2014). GPS \& GLONASS Mass-Market Receivers: Positioning Performances and Peculiarities. Sensors Vol. 14 No. 12: 22159-22179. November 2014: MDPI, Basel.

Ghilani, C. (2011). Adjustment computations: spatial data analysis. John Wiley \& Sons.

GSA. (2018). GNSS User Technology Report Issue 2. Publications Office of the European Union, Luksemburg.

Heister, Hans. (2008). The new ISO standard 17123-8 for checking GNSS field measuring systems (3069). FIG Working Week 2008, Stockholm, Swedia.

Hidayat, A. (2013). Uji F dan Uji T. Diakses pada 23 Januari 2019, dari: Statistikian: https://www.statistikian.com/2013/01/uji-f-dan-uji-t.html

ISO. (2015). ISO 17123-8:2015 - Optics and optical instruments - Field procedures for testing geodetic and surveying instruments - Part 8: GNSS field measurement systems in real-time kinematic (RTK). Geneva, Switzerland: ISO. 
Quraisy, A. (2014). Analisis Efektifitas Koreksi RTK CORS Terkait Panjang Baseline Base dengan Rover. Bandung: ITB.

Schwieger, V., dan Gläser, A. (2005). Possibilities of Low Cost GPS Technology for Precise Geodetic Applications From Pharaohs to Geoinformatics. FIG Working Week 2005 and GSDI-8, Kairo.

Tominaga, T., Kondo, K., Kubo, N., dan Yasuda, A. (2004). The Ionospheric Effect on Medium Baseline RTK-GPS Positioning. The 2004 International Symposium on GNSS/GPS. Sydney, Australia.

Zrinjski, M., Barkovic, D., dan Gabela, J. (2016). Review of the New International Test Standard for GNSS RTK Measurement Systems. International Symposium on Engineering Geodesy. Varaždin. 